\title{
Knowledge, attitude and practice of condom use by women of an impoverished urban area*
}

\author{
Conhecimento, atitude e prática de mulheres de um \\ aglomerado subnormal sobre preservativos
}

Conocimiento, actitud y práctica de mujeres que viven en un asentamiento irregular acerca de los preservativos

Smalyanna Sgren da Costa Andrade ${ }^{1}$, Ana Aline Lacet Zaccara ${ }^{2}$, Kamila Nethielly Souza Leite ${ }^{2}$, Karen Krystine Gonçalves de Brito ${ }^{1}$, Maria Júlia Guimarães Oliveira Soares ${ }^{3}$, Marta Miriam Lopes Costa ${ }^{3}$, Ana Karina Bezerra Pinheiro ${ }^{4}$, Simone Helena dos Santos Oliveira ${ }^{3}$

\footnotetext{
* Extracted from the dissertation "Mulheres solteiras e casadas e o uso do preservativo: o que sabem, pensam e praticam," Post-Graduate Program in Nursing, Universidade Federal da Paraíba, 2014.

${ }^{1}$ Doctorate degree student, CAPES Scholarship holder, Universidade Federal da Paraíba. João Pessoa, PB, Brazil.

${ }^{2}$ Master's degree, Universidade Federal da Paraíba. João Pessoa, PB, Brazil.

${ }^{3}$ Associate Professor, Universidade Federal da Paraíba, João Pessoa, PB, Brazil.

${ }^{4}$ Associate Professor, Universidade Federal do Ceará, Fortaleza, CE, Brazil.
}

\begin{abstract}
Objective: Assessing the adequacy of knowledge, attitude and practice of women regarding male and female condoms as STI/HIV preventive measures. Method: An evaluative Knowledge, Attitude and Practice (KAP) household survey with a quantitative approach, involving 300 women. Data collection took place between June and August 2013, in an informal urban settlement within the municipality of João Pessoa, Paraiba, Northeast Brazil. Results: Regarding the male condom, most women showed inadequate knowledge and practice, and an adequate attitude. Regarding the female condom, knowledge, attitude and practice variables were unsatisfactory. Significant associations between knowledge/religious orientation and attitude/education regarding the male condom were observed. Conclusion: A multidisciplinary team should be committed to the development of educational practices as care promotion tools in order to improve adherence of condom use.
\end{abstract}

\section{DESCRIPTORS}

Health Knowledge, Attitudes, Practice; Women; Condoms; Sexually Transmitted Diseases; Public Health Nursing. 


\section{INTRODUCTION}

Given the feminization of the HIV epidemiological profile, issues related to women's sexuality has attracted increasing attention, stressing the responsibility of users, managers and health professionals in controlling the epidemic. According to the World Health Organization, the lack of protection in sexual intercourse constitutes a significant risk factor for the transmission of sexually transmitted infections (STIs) and HIV worldwide, making condom use an essential element in reducing contamination cycles ${ }^{(1)}$.

In general, women experience obstacles in using condoms, whether it is the female condom by having difficulty in handling, unavailability or access, or the male condom, usually because its use depends on the partner. In this sense, a study conducted with 80 African-American men in attempt to evaluate their response upon request for condom use concluded that issues such as masculinity/chauvinism need to be addressed with heterosexual men, in order to facilitate negotiation between sexual partners ${ }^{(2)}$.

The relationship dynamics play an important role in STI contamination cycles, as some women cannot insist on condom use for various reasons, such as trusting her partner, fear of abandonment or sexual coercion caused by strong persuasion $^{(3)}$.

Gender relations become a determining factor for women with low sexual negotiation power on condom use, making them more vulnerable to HIV exposure ${ }^{(4)}$. In relation to single women, research has identified that this pattern of submission is no different; for those who seek serious commitment, they liked having unprotected sex with the same men with whom they had extended sexually-affective bonds ${ }^{(5)}$.

In addition to gender issues, other factors are also associated with not using condoms, such as low socioeconomic and cultural levels ${ }^{(6)}$. In this scenario, poverty detriments women; not only because of the difficulty in understanding information relevant to prevention, which involves knowledge, but also the subservient role to which they are subjected for not being income providers for the family ${ }^{(7)}$.

In this sense, a careful look at women's sexual health (single or married) is essential, especially those living in informal urban settlements (poor urban settlements) under precarious conditions. The study group has social characteristics that greatly resemble the profile of areas affected by the AIDS epidemic in Brazil. The interest in developing this study did not only arise because of the described scenario, but also as a reflection of the nurse's role as an agent responsible for health promotion and disease prevention in the field of sexuality.

Considering that knowledge, attitude and practice are presented as important components of diagnostic conjuncture toward condom use, this research will provide subsidies for the development of future educational strategies to facilitate the approach to STI/HIV in an interchangeable form with singularities of the referred group.

Therefore, the lack of knowledge about condom use or the existence of relegated knowledge attests to any individual as being susceptible to risk of STI and/or HIV contamination.
Through the influence of this factor - the adoption of protective measures against sexual infections, in particular the implementation of safe sexual practices - the question that guided the study was: Is the knowledge, attitude and practice of single and married women regarding condom use adequate? The question was answered by assessing the adequacy of knowledge, attitude and practice (KAP) of these women regarding male and female condoms and the association of these variables with sociodemographic characteristics (age, religion, education and marital status).

\section{METHOD}

A quantitative and evaluative Knowledge, Attitude and Practice (KAP) household survey was conducted. The population study was composed of women over 18 years of age, who had already started their sexual life, living in a poor area in the city of João Pessoa, PB. The research site was characterized by disordered occupation, precarious housing and areas of environmental risk.

From the data provided by the Basic Information System (SIAB) of the Municipal Health ${ }^{(8)}$, target population was statistically estimated as approximately 3,200 women registered in the local Integrated Family Healthcare Unit. The sample size was calculated based on an error margin of $5 \%($ Error $=0.05)$ with $\alpha=0.05\left(Z_{0,025}=1,96\right)$ and considering the true proportion of women who rely on condoms for prevention $23 \%(p=0.23)$. This proportion is the outcome of a survey conducted by the researchers, resulting in a sample of 251 women. Given the viability of interviewing a greater number of women, the sample was expanded to 300 participants.

The operational structure used for data collection was the Systematic Sampling Plan, which consists of approaching members of the community at regular intervals ${ }^{(9)}$, for example, starting from the main street (East to West direction), the first house where at least one sexually active adult woman resided as the starting point for the interviews.

From the first interview, three houses were skipped before the next interview. As the location has 2,134 households ${ }^{(10)}$, literature suggests a jump of 3-7 households for each selected street ${ }^{(11)}$. If that household did not have any women who met the inclusion criteria, the next house would be visited until the criterion was met, from where a new skip was initiated according to the method used. The household survey took place between June and August 2013 by the monitoring of Community Health Agents (CHA), covering all the micro areas of Integrated Healthcare Family Unit.

The KAP survey is a formative evaluation, which aims to collect data from a part of the population and promote the development of interventions ${ }^{(12)}$. In this study, knowledge can be defined as the recollection of specific facts (within the education system of which the individual is a part) or the ability to apply specific facts to solve problems; attitude is essentially having opinions. It's also having feelings, biases and beliefs, relatively constant, directed to a target, person or situation; and practice is "the decision-making in performing actions"(13-14).

The data collection instrument consisted of an interview form with questions involving sociodemographics. The 
KAP questionnaire applied was adapted from a model on condoms as a STI/HIV prevention method ${ }^{(14)}$. Variables on knowledge, attitude and practice about condoms were evaluated as described in the following paragraphs.

Knowledge was considered adequate or satisfactory when the women had heard about condoms, had knowledge that they prevent STI/HIV and unplanned pregnancy, and could mention at least three requirements for proper use. Attitude was considered adequate or satisfactory when women mention that using male or female condoms is always necessary for all sexual practices. Practice was adequate or satisfactory when women mention that using a condom from the beginning to the end of every sexual practice; has never had an unplanned pregnancy; has never been diagnosed with STI/ HIV. If the women did not meet the combined criteria, variables were classified as inadequate or unsatisfactory.

Data were compiled and analyzed with the aid of the Statistical Package for Social Sciences (SPSS), version 20.0. For associations between variables, the Pearson Chi-square Test and Fisher's Exact Test were used. Variables on knowledge, attitude and practice regarding the use of male and female condoms among single and married women were compared, as well as the suitability of the KAP, considering some demographic data (age, religion, education and marital status).

These associations were considered statistically significant when $\mathrm{p}$ (probability) was $\leq$ (less than or equal) to 0.05 in the tests. It is noteworthy that for statistical purposes, in relation to marital status, single, separated and widowed women were grouped into 'single', while married women or those in a consensual union were incorporated into the category 'married.'
The project was approved by the Research Ethics Committee of the Health Sciences Center, under research protocol N. 0251 and Presentation Certificate of Appreciation for Ethics N. 14726213.3.0000.5188, fulfilling the requirements of the National Health Council Resolution 466/12, which provides for standards and regulatory guidelines for research involving human beings ${ }^{(15)}$.

\section{RESULTS}

Of the interviewees, 114 (38\%) were 35 or older, 140 (46.67\%) did not work or were housewives, 218 (72.67\%) were Catholic, $182(60,67 \%)$ women finished high school/ primary education, $200(66.67 \%)$ were characterized as pardo (multiracial Brazilians), 189 (63\%) were married or living in stable unions and 192 (64\%) lived on up to 1 minimum wage.

Regarding the suitability of knowledge, attitude and practice of women surveyed on the male condom, 120 (40\%) women had adequate knowledge; 162 (54\%) had adequate attitude and $51(17 \%)$ had adequate practice. Regarding the female condom, 87 (29\%) had satisfactory knowledge, 96 (32\%) had appropriate attitudes and 1 $(0.33 \%)$ had practiced sexual intercourse with the female condom satisfactorily.

In Table 1, the association between sociodemographic variables (age, religion, education and marital status) and knowledge about male and female condoms is presented.

Table 2 shows results of the association between sociodemographic variables (age, religion, education and marital status) with attitudes related to the use of male and female condoms.

Table 1 - Association between sociodemographic and knowledge about male and female condoms - Joao Pessoa, PB, Brazil, 2014.

\begin{tabular}{|c|c|c|c|c|c|c|c|c|c|c|}
\hline & \multicolumn{4}{|c|}{ Male condom } & \multirow{3}{*}{ Significance } & \multicolumn{4}{|c|}{ Male condom } & \multirow{3}{*}{ Significance } \\
\hline & \multicolumn{2}{|c|}{ I $(n=180)$} & \multicolumn{2}{|c|}{$A(n=120)$} & & \multicolumn{2}{|c|}{ I $(n=213)$} & \multicolumn{2}{|c|}{$A(n=87)$} & \\
\hline & Freq. & $\%$ & Freq. & $\%$ & & Freq. & $\%$ & Freq. & $\%$ & \\
\hline \multicolumn{11}{|c|}{ AGE (YEARS) } \\
\hline$<25$ & 49 & 27.22 & 35 & 29.17 & \multirow{4}{*}{$\mathrm{p}^{(1)}=0.419$} & 57 & 26.76 & 27 & 31.03 & \multirow{4}{*}{$\mathrm{p}^{(1)}=0.412$} \\
\hline $25-30$ & 28 & 15.56 & 22 & 18.33 & & 32 & 15.02 & 18 & 20.69 & \\
\hline $30-35$ & 28 & 15.56 & 24 & 20.00 & & 40 & 18.78 & 12 & 13.79 & \\
\hline$\geq 35$ & 75 & 41.67 & 39 & 32.50 & & 84 & 39.44 & 30 & 34.48 & \\
\hline \multicolumn{11}{|c|}{ RELIGION } \\
\hline Catholic & 124 & 68.89 & 94 & 78.33 & \multirow{3}{*}{$\mathrm{p}^{(2)}=0.042$} & 152 & 71.26 & 66 & 75.86 & \multirow{3}{*}{$\mathrm{p}^{(2)}=0.707$} \\
\hline Evangelic/Spirit & 46 & 25.56 & 25 & 20.83 & & 53 & 24.88 & 18 & 20.69 & \\
\hline Others & 10 & 5.56 & 1 & 0.83 & & 8 & 3.76 & 3 & 3.45 & \\
\hline \multicolumn{11}{|c|}{ EDUCATION LEVEL } \\
\hline None & 8 & 4.44 & 2 & 1.67 & \multirow{4}{*}{$\mathrm{p}^{(1)}=0.487$} & 10 & 4.69 & 0 & 0 & \multirow{4}{*}{$\mathrm{p}^{(2)}=0.115$} \\
\hline Primary Education & 111 & 61.67 & 71 & 59.17 & & 131 & 61.50 & 51 & 58.62 & \\
\hline Secondary Education & 58 & 32.22 & 44 & 36.67 & & 68 & 31.92 & 34 & 39.08 & \\
\hline Superior Education & 3 & 1.67 & 3 & 2.50 & & 4 & 1.88 & 2 & 2.30 & \\
\hline \multicolumn{11}{|c|}{ MARITAL STATUS } \\
\hline Single & 64 & 35.56 & 47 & 39.17 & \multirow[b]{2}{*}{$\mathrm{p}^{(1)}=0.544$} & 72 & 33.80 & 39 & 44.83 & \multirow[b]{2}{*}{$\mathrm{p}^{(1)}=0.087$} \\
\hline Married & 116 & 64.44 & 73 & 60.83 & & 141 & 66.20 & 48 & 55.17 & \\
\hline
\end{tabular}

Inadequate $=(\mathrm{I})$; Adequate $=(\mathrm{A}) \cdot{ }^{(1)}$ Chi-square ${ }^{(2)}$ Test Fisher's Exact Test. 
Table 2 - Association between sociodemographic and attitudes related to the use of male and female condoms - Joao Pessoa, PB, Brazil, 2014.

\begin{tabular}{|c|c|c|c|c|c|c|c|c|c|c|}
\hline & \multicolumn{4}{|c|}{ Male condom } & \multirow{3}{*}{ Significance } & \multicolumn{4}{|c|}{ Male condom } & \multirow{3}{*}{ Significance } \\
\hline & \multicolumn{2}{|c|}{ I (n=138) } & \multicolumn{2}{|c|}{$A(n=162)$} & & \multicolumn{2}{|c|}{ I (n=204) } & \multicolumn{2}{|c|}{$A(n=96)$} & \\
\hline & Freq. & $\%$ & Freq. & $\%$ & & Freq. & $\%$ & Freq. & $\%$ & \\
\hline \multicolumn{11}{|c|}{ AGE (YEARS) } \\
\hline$<25$ & 40 & 28.99 & 44 & 27.16 & \multirow{4}{*}{$\mathrm{p}^{(1)}=0.795$} & 58 & 28.43 & 26 & 27.08 & \multirow{4}{*}{$\mathrm{p}^{(1)}=0.656$} \\
\hline $25-30$ & 22 & 15.94 & 28 & 17.28 & & 33 & 16.18 & 17 & 17.71 & \\
\hline $30-35$ & 21 & 15.22 & 31 & 19.14 & & 32 & 15.69 & 20 & 20.83 & \\
\hline$\geq 35$ & 55 & 39.86 & 59 & 36.42 & & 81 & 39.71 & 33 & 34.38 & \\
\hline \multicolumn{11}{|c|}{ RELIGION } \\
\hline Catholic & 102 & 73.91 & 116 & 71.60 & \multirow{3}{*}{$\mathrm{p}^{(2)}=0.813$} & 148 & 72.55 & 70 & 72.92 & \multirow{3}{*}{$\mathrm{p}^{(2)}=0.888$} \\
\hline Evangelic/Spirit & 32 & 23.19 & 39 & 24.07 & & 49 & 24.02 & 22 & 22.92 & \\
\hline Others & 4 & 2.90 & 7 & 4.32 & & 7 & 3.43 & 4 & 4.17 & \\
\hline \multicolumn{11}{|c|}{ EDUCATION LEVEL } \\
\hline None & 9 & 6.52 & 1 & 0.62 & \multirow{4}{*}{$\mathrm{p}^{(1)}=0.003$} & 9 & 4.41 & 1 & 1.04 & \multirow{4}{*}{$\mathrm{p}^{(2)}=0.529$} \\
\hline Primary Education & 90 & 65.22 & 92 & 56.79 & & 123 & 60.29 & 59 & 61.46 & \\
\hline Secondary Education & 37 & 26.81 & 65 & 40.12 & & 68 & 33.33 & 34 & 35.42 & \\
\hline Superior Education & 2 & 1.45 & 4 & 2.47 & & 4 & 1.96 & 2 & 2.08 & \\
\hline \multicolumn{11}{|c|}{ MARITAL STATUS } \\
\hline Single & 52 & 37.68 & 59 & 36.42 & \multirow[b]{2}{*}{$\mathrm{p}^{(1)}=0.905$} & 76 & 37.25 & 35 & 36.46 & \multirow[b]{2}{*}{$\mathrm{p}^{(1)}=0.899$} \\
\hline Married & 86 & 62.32 & 103 & 63.58 & & 128 & 62.75 & 61 & 63.54 & \\
\hline
\end{tabular}

Table 3 shows the result of the association between sociodemographic variables and the use (practice) of male condoms. It was not possible to analyze the as- sociation between the variables and the use (practice) of the female condom since only one occurrence for proper use was found.

Table 3 - Association between sociodemographic and use of condoms - Joao Pessoa, PB, 2014.

\begin{tabular}{|c|c|c|c|c|c|}
\hline & \multicolumn{4}{|c|}{ Male condom } & \multirow{3}{*}{ Significance } \\
\hline & \multicolumn{2}{|c|}{ I $(n=249)$} & \multicolumn{2}{|c|}{$A(n=51)$} & \\
\hline & Freq. & $\%$ & Freq. & $\%$ & \\
\hline \multicolumn{6}{|c|}{ AGE (YEARS) } \\
\hline$<25$ & 64 & 25.70 & 20 & 39.22 & \multirow{4}{*}{$\mathrm{p}^{(1)}=0.199$} \\
\hline $25-30$ & 41 & 16.47 & 9 & 17.65 & \\
\hline $30-35$ & 44 & 17.67 & 8 & 15.69 & \\
\hline$\geq 35$ & 100 & 40.16 & 14 & 27.45 & \\
\hline \multicolumn{6}{|c|}{ RELIGION } \\
\hline Catholic & 179 & 71.89 & 39 & 76.47 & \multirow{3}{*}{$\mathrm{p}^{(2)}=0.086$} \\
\hline Evangelic/Spirit & 63 & 25.30 & 8 & 15.69 & \\
\hline Others & 7 & 2.81 & 4 & 7.84 & \\
\hline \multicolumn{6}{|c|}{ EDUCATION LEVEL } \\
\hline None & 9 & 3.61 & 1 & 1.96 & \multirow{4}{*}{$\mathrm{p}^{(2)}=0.218$} \\
\hline Primary Education & 156 & 62.65 & 26 & 50.98 & \\
\hline Secondary Education & 80 & 32.13 & 22 & 43.14 & \\
\hline Superior Education & 4 & 1.61 & 2 & 3.92 & \\
\hline \multicolumn{6}{|c|}{ MARITAL STATUS } \\
\hline Single & 86 & 34.54 & 25 & 49.02 & \multirow[b]{2}{*}{$\mathrm{p}^{(1)}=0.057$} \\
\hline Married & 163 & 65.46 & 26 & 50.98 & \\
\hline
\end{tabular}

Inadequate $=(\mathrm{I}) ;$ Adequate $=(\mathrm{A})^{(1)}$ Chi-square ${ }^{(2)}$ Test Fisher's Exact Test. 
For adequate practice, women must meet the combined criteria. Failing to meet any of the criteria already attests to inappropriate practice. Therefore, 100 (33.3\%) women had unplanned pregnancy and $34(11.3 \%)$ were diagnosed with STIs or HIV. Regarding the male condom, 78 (26\%) women reported using it in some sexual activities, 137 (45.7\%) never used it in any sexual activity and 187 (62.3\%) did not use it from start to finish. For the female condom, 15 (5\%) reported using it in some sexual activities, 283 (94.3\%) never used it in any sexual activity and 285 (95\%) did not use it from start to finish.

Table 4 describes the association between knowledge and attitude with the use of condoms.

Table 4 - Association of knowledge and attitude with practice/ use of condoms - Joao Pessoa, PB, Brazil, 2014.

\begin{tabular}{lccccc}
\hline & \multicolumn{5}{c}{ Practice } \\
\cline { 2 - 4 } & \multicolumn{4}{c}{ Adequate } & \multicolumn{2}{c}{ Inadequate } & Significance \\
\cline { 2 - 4 } & Freq. & $\%$ & Freq. & $\%$ & \\
\hline Adequate & 25 & 49.02 & 95 & 38.15 & $\mathrm{p}=0.198$ \\
Inadequate & 26 & 50.98 & 154 & 61.85 & \\
\hline \multicolumn{5}{c}{ Attitude } \\
\hline Adequate & 45 & 88.24 & 117 & 46.99 & $\mathrm{p}<0.001$ \\
Inadequate & 6 & 11.76 & 132 & 53.01 & \\
\hline Chi-square Test. & \multicolumn{5}{c}{} \\
\hline
\end{tabular}

\section{DISCUSSION}

For sociodemographic characteristics, the majority of women were unemployed, with little education and poor monthly income. Data is in accordance with the location status of the research site. A similar profile is observed in women living with AIDS in Brazil.

Moreover, if only this characterization were considered, perhaps there would be the possibility (risk) of contamination of these participants, given the impact of social and economic level for the perpetuation of the epidemic. Research emphasizes that the profile of women living with HIV/AIDS is characterized by incomplete education, unemployment (housewives) or employment in low-skill services $^{(16-17)}$.

In relation to the data described for the suitability of the knowledge, attitude and practice, most possessed little knowledge of the male condom, although a large part of the study of women had proper attitude toward its use. However, it became clear that only believing that the use of condoms is necessary in all relationships and sexual practices does not endorse its concrete use.

KAP inadequacy on the female condom may reaffirm the little access to information and the scarce availability of this method in health services. In this case, it is believed that the lack of knowledge can lead to inadequate opinions and result in the non-use of condoms. These results demonstrate that the approach of this prevention method is still insignificant among women of the community.

Research conducted in a family planning program in Salvador, Bahia, showed that $60 \%$ of participants did not use condoms. For researchers, the use is not part of Brazilian culture and contraceptive adoption depends on male agreement, which is a setback to prevention since they do not like barrier methods, believing that these interfere with sexual pleasure ${ }^{(18)}$.

Unfortunately, female submission is still strong in the national context, interfering with decision-making and sexual freedom, exposing them even more to the risk of AIDS and other STI epidemics. The inclusion of men in preventive strategies constitutes a positive turning point in coping with these diseases, since their behavior directly affects their partner`s health ${ }^{(19)}$.

Research conducted in Campinas-SP with 295 university students about the birth control pill and condom use revealed that knowledge and attitude were adequate, but the practice was unsatisfactory for both genders ${ }^{(20)}$. Similarly, the Family Development Center/Natural Birth Center, an agency of the Universidade Federal do Ceará, developed a KAP research with 35 women before and after an educational intervention on the female condom. Pre-test results indicated that $48.6 \%$ women had moderate knowledge; $34.3 \%$ had inadequate attitude; $97.1 \%$ had inadequate practice $^{(21)}$.

After health education, $85.3 \%$ had adequate knowledge, $62.9 \%$ moderate attitude and $55.9 \%$ substantial practice. Researchers concluded that women were willing to use the female condom after effective educational interventions were carried out ${ }^{(21)}$.

Similarly, a randomized study of 715 African-American adolescents, with an objective to access the frequency of communication between partners about the use of condom before and after an intervention on HIV risk reduction, showed that the request for condom use and subsequent use increased significantly after the intervention. Therefore, in this study, the effective intervention was associated with condom use ${ }^{(22)}$.

In this context, risks involve each individual and the possible causation existing between the conditions that may or may not cause any pathology ${ }^{(23)}$. Preventive STIs and HIV actions aimed at reducing contamination risks, including the commitment on production and transmission of knowledge according to the particularities of each situation and the resources for solving them ${ }^{(24)}$.

Another KAP research on the use of male and female condoms involving 155 prisoners showed that $22.6 \%$ had adequate knowledge about male condoms, and $7.1 \%$ regarding the female. Proper practice of female condoms had little representation. Factors such as sexual orientation, gender issues, lack of knowledge and poor access to condoms constituted barriers to sexual health promotion of the study group ${ }^{(14)}$.

Internationally, a study with 100 women living in rural Karashi, Pakistan, found low contraceptive use among women, despite good knowledge. Positive attitude towards contraception was shown in $76 \%$ among those surveyed ${ }^{(25)}$.

Another KAP study performed with 824 American university students showed that $63.8 \%$ of respondents reported having used a condom during their last sexual intercourse. The 
use was proportionally higher among students whose mothers had higher education. It was concluded that strategies to stop sexual transmission of HIV should include the mother's educational role in disseminating knowledge and encouraging the consistent use of condoms by their children ${ }^{(26)}$.

In this study, it is noted that educational interventions were developed in an attempt to strengthen assistance, to ensure better access to information and greater adherence to condom use. On those occasions, the strategies outlined by the researchers mainly involved the continuous education for health professionals and health education for the participants in order to promote behavioral changes to reduce disease transmission cycles.

The use of female condom is still somewhat new among the Brazilian population. Despite resistance to its use, this method is valuable in the sense of broadening the perspectives of STIs and HIV prevention among women. The problem of its use lies in its difficult access and sparse distribution in health facilities, as it is often found less frequently and at lower quantities than the male condom ${ }^{(18)}$.

Table 1 shows no association between adequacy of knowledge on male and female condoms, considering age, education and marital status, since $\mathrm{p}$-values were greater than 0.05 ( $p>0.05)$. This means that proper knowledge is independent of the characteristics of women, from the analyzed variables.

The exception to this is observed in religious orientation, where knowledge about the male condom among Catholics is more appropriate than among women of other religions and among those with inadequate knowledge, although a higher proportion of Catholics among women with inadequate knowledge can also be observed. Higher proportions of evangelican/spiritualistic women with inadequate knowledge can be observed in comparison to those with adequate knowledge.

Religious beliefs supposedly regulate and inspire human behavior. Whether conservative or liberal, all behaviors are peculiarly based on religious devotion. Therefore, religiosity grounds ethical decisions, concepts, prejudices and behaviors of people on issues of social interest.

In the present study, the reasons for why Catholics had better knowledge on condoms were not analyzed, but the association between religious beliefs and the variables of the KAP were. Results show that the modern Catholic woman possibly understands their sexuality as something independent of the traditionalism imposed by the church, with knowledge on condom use being more appropriate than for Evangelicals and Spiritualists.

In Table 2, considering the attitude towards the use of male condoms, schooling shows a significant association ( $p$ $=0.05$ ) with adequacy, demonstrating a higher proportion of women with secondary education or more with proper attitude compared to those with the same education level with inadequate attitude. Conversely, those with primary education or no education have higher proportions of inadequacy than attitude adequacy.

Results show that higher levels of education contribute to positive attitudes towards condom use, reaffirming access to education as an influential method in designing better habits for disease prevention. Regarding the female condom, no significance to any socio-demographic variable was found.

As for practice, the fact that only one woman referred to using the female condom prevents the analysis of the association with sociodemographic data, therefore the focus was on male condom use. It was found that none of the sociodemographic variables were significantly associated with practice. It should be noted, however, that married women had higher proportions of inadequate behavior than single women, and that for this variable, the $\mathrm{p}$ value approached the significance value (Table 3 ).

Regarding this, a population-based research on the use of condoms during sexual intercourse showed statistically significant differences about the use of condoms associated to marital status, where single women (single, widowed or separated) used condoms more often and regularly than married women or those in a stable relationship ${ }^{(27)}$.

These findings once again demonstrate that the union stability influences the failure to use condoms as a STI and HIV prevention method. Women in stable relationships probably do not realize their risky sexual behavior, as their confidence in monogamy allows unprotected sex with their partner, making them susceptible to possible contamination.

Table 4 shows no association of knowledge with the use of condoms, observing higher frequencies of inappropriate practices. The analysis of proportionalities among women with adequate practice reveals greater proportion of adequacy among those with inadequate knowledge, the same happens for women with inadequate knowledge.

Attitude and practice were significantly associated ( $\mathrm{p}=$ 0.05 ), and it was observed that, although the frequency of inappropriate practices are predominant in the study group and even among women with proper attitude, in the group with adequate practice most women also show proper attitude, while among those with inadequate practice, most have inadequate attitudes (Table 4).

Investigations on the same theme have shown that women with adequate knowledge had higher percentages of appropriate attitudes, but did not use a condom properly. All of these studies found no significant associations between the components of the knowledge, attitude and practice of condom use $\mathrm{in}^{(14,20,25)}$.

Regarding knowledge of condom use, a study of 375 sexually active African-American and Hispanic workers showed that the group with the most knowledge/ability to put a condom on an anatomical model was also the one which reported using condoms more during sexual activity. The authors concluded that knowledge influences condom use among participants ${ }^{(28)}$.

Some factors present obstacles to adherence to measures for prevention of STIs and HIV, sometimes these are more relevant than the lack of knowledge, such as gender relations linked to the difficulty of condom use agreement ${ }^{(6)}$. However, it cannot fail to be stressed that, despite assuming favorable attitudes, women often face fragile knowledge that does not maintain proper practice ${ }^{(4)}$. 
In this sphere, the individual having knowledge and a positive attitude can facilitate the adoption of preventive behaviors, and this practice is not assured without adequate support that favors behavior changes towards condom use. Considering the location of the study, factors such as violence, education level and living conditions may constitute as barriers to the continuous work process of the healthcare team, encompassing these women in the broad context of vulnerability (individual, social and cultural).

\section{CONCLUSION}

It was concluded that regarding the male condom, most women had inadequate knowledge and practice, but satisfactory attitude. For the female condom, KAP was inappropriate for a substantial majority. Religious orientation was significantly associated with adequate knowledge, while education was significantly associated with adequate attitude, both regarding male condoms. The relationship of attitude/practice was significant among single and married women, the same did not occur in association of knowledge/practice.

Some possible solutions to the scenario described are community activities of an educational nature, such as the preparation of annual week-long health fairs, in partnership with the city and state health departments with support of health professionals. In addition, the training of health pro- fessionals who work in the Family Healthcare Unit (FHU) concerning the proper approach to this subject, offering and making condoms available to users, increasing access and strengthening the chances of use.

Other routine actions could be developed at the FHU, such as the creation of a group intended for the male audience, sensitizing them to care for their own health among other issues, and healthy sexual practices with the use of condoms as a preventive method of STIs and HIV infection.

In this regard, we emphasize nursing as a profession based on the development of educational practices, which are very important tools for care practice. Strengthening the role of nurses as a social worker is essential for sharing knowledge related to condom use which is important for HIV and STI prevention. Actions could be carried out in the waiting room or during nursing consultations.

A limitation of the study is the specificity of the women interviewed, because the demographic profile characterises a poor community, and so information acquired for this group should not be generalized to all women in the municipality. Further investigations should be encouraged related to the health impacts of health education on condoms, especially on the incipient use of the female condom, as well as KAP studies and condom use in men, due to the strong influence of their sexual behavior on women.

\section{RESUMO}

Objetivo: Avaliar a adequabilidade do conhecimento, da atitude e prática de mulheres acerca de preservativos masculino e feminino enquanto medida preventiva às IST/HIV. Método: Inquérito domiciliar, avaliativo do tipo conhecimento, atitude e prática (PAC), de abordagem quantitativa, envolvendo 300 mulheres. A coleta de dados ocorreu entre junho e agosto de 2013, em um aglomerado subnormal do município de João Pessoa. Resultados: Para o preservativo masculino, a maioria das mulheres apresentou conhecimento e prática inadequados e atitude adequada. Em relação ao preservativo feminino, as variáveis conhecimento, atitude e prática foram insatisfatórias. Houve associações significativas entre conhecimento/orientação religiosa e atitude/escolaridade para o preservativo masculino. Conclusão: A equipe multiprofissional deve estar compromissada com o desenvolvimento de práticas educativas como ferramentas de promoção do cuidado, no sentido de favorecer a adesão ao uso de preservativos.

\section{DESCRITORES}

Conhecimentos, Atitudes e Prática em Saúde; Mulheres; Preservativos; Doenças Sexualmente Transmissíveis; Enfermagem em Saúde Pública.

\section{RESUMEN}

Objetivo: Evaluar la adecuabilidad del conocimiento, la actitud y la práctica de mujeres acerca de los preservativos masculino y femenino en cuanto medida preventiva a las IST/VIH. Método: Encuesta domiciliaria, evaluadora del tipo conocimiento, actitud y práctica (PAC), de abordaje cuantitativo, incluyendo a 300 mujeres. La recolección de datos ocurrió entre junio y agosto de 2013, en un asentamiento irregular (barrio de chozas) del municipio de João Pessoa. Resultados: Para el preservativo masculino, la mayoría de las mujeres demostró conocimiento y práctica inadecuados y actitud adecuada. Con respecto al preservativo femenino, las variables conocimiento, actitud y práctica fueron insatisfactorias. Hubo asociaciones significativas entre conocimiento/orientación religiosa y actitud/escolaridad para el preservativo masculino. Conclusión: El equipo multiprofesional debe tener compromiso con el desarrollo de prácticas educativas como herramientas de promoción del cuidado, a fin de favorecer la adhesión al uso de los preservativos.

\section{DESCRIPTORES}

Conocimientos, Actitudes y Práctica en Salud; Mujeres; Condones; Enfermedades de Transmisión Sexual; Enfermería en Salud Pública.

\section{REFERENCES}

1. World Health Organization (WHO). Consolidated guidelines on HIV prevention, diagnosis, treatment and care for key populations [internet]. 2014 [cited 2014 July 22]. Available from: http://www.paho.org/bra/images/stories/Documentos2/eng\%20guias\%20pop\%20 vul\%20who-1.pdf?ua=1 
2. Raiford JL, Seth P, Braxton ND, DiClemente RJ. Masculinity, condom use self-efficacy and abusive responses to condom negotiation: the case for HIV prevention for heterosexual African-American men. Sex Health [Internet]. 2013 [cited 2014 Oct 22];10(5):467-9. Available from: http://www.ncbi.nlm.nih.gov/pubmed/23838050

3. Cordeiro F, Heilborn ML, Cabral CS, Moraes CL. Entre negociação e conflito: gênero e coerção sexual em três capitais brasileiras. Ciênc Saúde Coletiva [Internet]. 2009 [citado 2014 ago. 17];14(4):1051-62. Disponível em: http://www.scielo.br/pdf/csc/v14n4/a07v14n4.pdf

4. Santos NJS, Barbosa RM, Pinho AA, Villela WV, Aidar T, Filipe EMV. Contextos de vulnerabilidade para o HIV entre mulheres brasileiras. Cad Saúde Pública [Internet]. 2009 [citado 2013 out. 10];25 Supl. 2:321-33. Disponível em: http://www.scielo.br/pdf/csp/v25s2/14.pdf

5. Souza Filho EA, Beldarrain-Durandegui A. Representações e comunicações sobre prevenção ao HIV/aids em meio popular. Interação Psicol [Internet]. 2011 [citado 2013 out. 10];15(2): 159-67. Disponível em: http://ojs.c3sl.ufpr.br/ojs2/index.php/psicologia/article/ view/16234/18303

6. Andrade SSC, Silva FMC, Sousa e Silva MS, Oliveira SHS, Montenegro SMSL. Prevenção de vulvovaginite: utilizando as falas das mulheres para elaboração de orientações em saúde. Rev Enferm UFPE On Line [Internet]. 2012 [citado 2014 mar.12];6(2):339-45. Disponível em: http://www.ufpe.br/revistaenfermagem/index.php/revista/

7. Guedes RN, Fonseca RMGS, Egry EY. The evaluative limits and possibilities in the family health strategy for gender-based violence. Rev Esc Enferm USP [Internet]. 2013 [cited 2013 Sept 29];47(2):304-11. Available from: http://www.scielo.br/pdf/reeusp/v47n2/en_05.pdf

8. Brasil. Ministério da Saúde; Secretaria de Assistência à Saúde. DATASUS. Sistema de Informação da Atenção Básica (SIAB). Consolidado das famílias cadastradas no ano de 2013. João Pessoa: SIAB; 2013.

9. Rouquayrol MZ, Gurgel M. Epidemiologia e saúde. $7^{a}$ ed. Rio de Janeiro: MedBook; 2013.

10. Instituto Brasileiro de Geografia e Estatística. Censos Demográficos. Aglomerados subnormais: informações territoriais. Rio de Janeiro: IBGE; 2010.

11. Babbie E. Métodos de pesquisas de survey. Belo Horizonte: UFMG; 2005.

12. Brasil. Ministério da Educação; Instituto Nacional do Desenvolvimento da Educação. Manual do aplicador do estudo CAP. Brasília: MEC; 2002.

13. Marinho LAB, Costa-Gurgel MS, Cecatti JG, Osis MJD. Conhecimento, atitude e prática do auto-exame das mamas em centros de saúde. Rev Saúde Pública [Internet]. 2003 [citado 2013 nov. 12];37(5):576-82. Disponível em: http://www.scielo.br/pdf/rsp/v37n5/17471.pdf

14. Nicolau AIO, Ribeiro SG, Lessa PRA, Monte AS, Bernardo EBR, Pinheiro AKB. Knowledge, attitude and practices regarding condom use among women prisoners: the prevention of STD/HIV in the prison setting. Rev Esc Enferm USP [Internet]. 2012 [cited 2012 Oct 10];46(3):711-9. Available from: http://www.scielo.br/pdf/reeusp/v46n3/en_25.pdf

15. Brasil. Ministério da Saúde; Conselho Nacional de Saúde. Resolução n. 466, de 12 de dezembro de 2012. Dispõe sobre as diretrizes e normas regulamentadoras de pesquisas envolvendo seres humanos [Internet]. Brasília; 2012 [citado 2013 set. 22]. Disponível em: http:/l conselho.saude.gov.br/resolucoes/2012/Reso466.pdf

16. Gaspar J, Reis RK, Pereira FMV, Neves LAS, Castrighini CC, Gir E. Quality of life in women with HIV/AIDS in a municipality in the State of São Paulo. Rev Esc Enferm USP [Internet]. 2011 [cited 22 Sept 2013];45(1):230-6. Available from: http://www.scielo.br/pdf/reeusp/ v45n1/en_32.pdf

17. Felix G, Ceolim MF. The profile of women with HIV/AIDS and their adherence to the antiretroviral therapy. Rev Esc Enferm USP [Internet]. 2012 [cited 2013 Sept 18];46(4):884-91. Available from: http://www.scielo.br/pdf/reeusp/v46n4/en_15.pdf

18. Rivemales MCC, Almeida GM, Queiroz MMA. Adesão de mulheres ao uso do preservativo em um programa de planejamento familiar de Salvador, Bahia. Rev Enferm UFPE On Line [Internet]. 2009 [citado 2013 ago. 12];3(1). Disponível em: http://www.revista.ufpe.br/ revistaenfermagem/index.php/revista/article/viewArticle/262

19. Silva CM, Vargens OMC. Women's perception about female vulnerability to STD and HIV. Rev Esc Enferm USP [Internet]. 2009 [cited 2013 Oct 23];43(2):401-6. Available from: http://www.scielo.br/pdf/reeusp/v43n2/en_a20v43n2.pdf

20. Alves AS, Lopes MHBM. Locus of control and contraceptive knowledge, attitude and practice among university students. Rev Saúde Pública [Internet]. 2010 [cited 2013 Dec 17];44(1):39-44. Available from: http://www.scielo.br/pdf/rsp/v44n1/04.pdf

21. Fernandes RLV, Moura ERF, Feitoza AR, Evangelista DR, Oriá MOB. Conhecimento, atitude e prática relacionados ao preservativo feminino. Rev RENE. 2012;13(4):755-65.

22. Sales JM, Lang DL, DiClemente RJ, Latham TP, Wingood GM, Hardin JW, et al. The mediating role of partner communication frequency on condom use among African American adolescent females participating in an HIV prevention intervention. Health Psychol. 2012;31(1):63-9.

23. Schaurich D, Freitas HMB. The HIV/AIDS vulnerability framework applied to families: a reflection. Rev Esc Enferm USP [Internet]. 2011 [cited 2013 Oct 17];45 (4):989-95. Available from: http://www.scielo.br/pdf/reeusp/v45n4/en_v45n4a28.pdf

24. Reis RK, Gir E. Vulnerability and prevention of sexual HIV transmission among HIV/AIDS serodiscordant couples. Rev Esc Enferm USP [Internet]. 2009 [cited 29 Sept 2013];43(3):662-9. Available from: http://www.scielo.br/pdf/reeusp/v43n3/en_a23v43n3.pdf

25. Mustafa R, Afreen U, Hashmi HA. Conhecimento contraceptivo, atitude e prática entre as mulheres rurais. Coll J Surg Médicos Pak. 2008;18(9):164-70.

26. El Bcheraoui C, Sutton MY, Hardnett FP, Jones SB. Patterns of condom use among students at historically Black colleges and universities: implications for HIV prevention efforts among college-age young adults. AIDS Care. 2013;25(2):186-93.

27. Carreno I, Costa JSD. Uso de preservativos nas relações sexuais: estudo de base populacional. Rev Saúde Pública [Internet]. 2006 [citado 21 Sept 2013];40(4):720-6. Disponível em: http://www.scielo.br/pdf/rsp/v40n4/en_24.pdf

28. Rubens M, McCoy HV, Shehadeh N. Proficiency in condom use among migrant workers. J Assoc Nurses AIDS Care. 2014;25(3):233-42. 